\title{
Lateral Decubitus vs Supine Positioning in Surgical Treatment of Hip Fractures with Proximal Femoral Nailing in Geriatric Patients: Whis is more suitable?
}

\author{
Özgün Araştırma \\ Research Article \\ Geriyatrik Hasta Grubu Kalça Kırıklarında PFN \\ Uygularken Supin Pozisyon vs Lateral Pozisyon: \\ Hangisi daha uygun?
}

\section{Tolgahan Kuru $\odot$}

\begin{abstract}
Objective: Intertrochanteric femoral fractures account for more than half of all hip fractures. Proximal femoral nailing is one of the most common methods used in the treatment of these fractures. However, there is no definitive consensus on the best positioning when performing proximal femoral nailing in hip fractures, especially in geriatric patients. The objective of this study was to compare supine and lateral decubitus positioning approach in surgical treatment of intertrochanteric femoral fractures with proximal femoral nailing method in geriatric patients.

Method: Patients aged over 65 years treated due to intertrochanteric fractures with proximal femoral nailing method were included in the study. Patients' position during the procedure, number of shots received from portable $X$-ray device, postoperative amount of blood loss, operative time, duration of postoperative follow-up, presence of postoperative bleeding, perioperative complications and postoperative long-term complications were also recorded and compared between the patients operated in supine and lateral positions.

Results: There was a statistically significant between both groups in terms of the average operative times, and average operative time was significantly shorter in the lateral positioning group ( $p=0.01)$. No significant difference was found between the two groups in terms of the amount of postoperative bleeding $(p=0.088)$. There was a statistically significant difference between both groups and the mean number of $X$-rays received during the procedures were significantly lower in the lateral positioning group $(p=0.010)$.

Conclusion: Lateral positioning in surgical treatment of intertrochanteric fractures with proximal femoral nailing method seems to have several advantages over supine position including reduced operative times, blood loss and imaging exposure.
\end{abstract}

Keywords: Intertrochanteric fractures, proximal femoral nailing, supine, lateral, geratric

\section{öz}

Amaç: intertrokanterik femur kırıkları tüm kalça kırıklarının yarısından fazlasını oluşturmaktadır. Proksimal femoral çivileme, bu kırıkların tedavisinde kullanılan en yaygın yöntemlerden biridir. Ancak özellikle geriatrik hastalarda bu yöntem uygulanırken hangi pozisyonun en uygun olduğu konusunda tam bir görüş birliği yoktur. Bu çalışmanın amacı, geriatrik hastalarda intertrokanterik femur kırıklarının proksimal femoral çivileme ile cerrahi tedavisinde supin ve lateral pozisyon yaklaşımlarını karşılaştırmaktır.

Yöntem: Intertrokanterik kırık nedeniyle proksimal femoral çivileme ile tedavi edilen 65 yaş üzeri hastalar çalışmaya dahil edildi. Hastaların prosedür sırasındaki pozisyonu, alınan X-ray sayıları, postoperatif kan kaybı miktarı, operasyon süresi, izlem süresi, perioperatif ve postoperatif komplikasyonları kaydedilerek supin ve lateral pozisyonlarda opere edilen hastalar arasında karşılaştıııldı.

Received/Geliş: 28.12 .2019 Accepted/Kabul: 04.01.2020 Published Online: 31.08 .2020

Bulgular: Her iki grup arasında operasyon süresi açısından anlamlı fark mevcut olup, ortalama operasyon süresi lateral grupta daha düşük olarak saptandı $(p=0,01)$. Postoperatif kanama açııından iki grup arasında anlamlı fark saptanmadı $(p=0,088)$. Prosedür sırasında alınan X-ray görüntü sayısı lateral pozisyon grubunda anlamlı olarak daha düşük saptandı $(p=0,010)$.

Sonuç: Intertrokanterik kırıkların proksimal femoral çivileme yöntemi ile cerrahi tedavisinde lateral pozisyonun, supin pozisyona göre daha kısa operasyon zamanı, daha düşük postoperatif kanama miktarı ve daha az sayıda X-ray görüntüleme alınması gibi avantajları bulunduğu görünmektedir.

Canakkale Onsekiz Mart Üniversitesi Tıp Fakültesi,

Ortopedi ve Travmatoloji Ana Bilim Dalı,

Çanakkale - Türkiye

mdtolgahankuru@gmail.com ORCID: 0000-0003-1245-6390

Cite as: Kuru T. Geriyatrik hasta grubu kalça kiriklarinda PFN uygularken supin pozisyon vs lateral pozisyon: Hangisi daha uygun?. Tepecik Eğit. ve Araşt. Hast. Dergisi. 2020;30(2):127-32.

Anahtar kelimeler: Intertrokanterik kırıklar, proksimal femoral çivileme, supin, lateral, geriyatrik

(C) Telif hakkı T.C. Să̆lık Bakanlığı İmir Tepecik Eğit. ve Arastt. Hastanesi. Logos Tıp Yayınclık tarafindan yayınlanmaktadır.

Bu dergide yayınlanan bütün makaleler Creative Commons Atf-GayriTicari 4.0 Uluslararası Lisansı ile lisanslanmıştır.

(c) Copyright Association of Publication of the T.C. Ministry of Health Izmir Tepecik Education and Research Hospital.

This journal published by Logos Medical Publishing.

Licenced by Creative Commons Attribution-NonCommercial 4.0 International (CC BY) 


\section{INTRODUCTION}

The incidence of hip fractures is increasing among elderly people in parallel with increasing life expectancy. The number of hip fractures is estimated to reach 6.3 million by $2050^{(1)}$.

Especially among geriatric patients with limited physical activity, 20 to $30 \%$ of them with intertrochanteric fractures die within 12 months after developing these fractures ${ }^{(2,3)}$. Intertrochanteric and subtrochanteric femoral fractures account for more than half of all hip fractures ${ }^{(4)}$. Treatment methods for these fractures include conservative treatment, open or closed reduction, internal fixation with different implants and arthroplasty. The most commonly used surgical method for intertrochanteric fractures is internal fixation, and fixation with intramedullary (nails) and extramedullary (screws and plates) are among commonly used approaches ${ }^{(5)}$. High rates of complications and poor outcomes have been reported in fixation of unstable fractures with plates and screws ${ }^{(6)}$. Treatment strategies have focused on the use of intramedullary nails instead of plating and hip screws. Fixation of these fractures with proximal femoral nailing (PFN) requires minimal surgical incision ${ }^{(7)}$. According to the $A O$ classification, fixation of unstable fracture types $A 2$ and $A 3$ require a surgeon experienced in these fractures ${ }^{(8)}$.

Several studies have discussed advantages and disadvantages of various positioning approaches for proximal femoral nailing method. When fixation of hip fractures is indicated, routinely used method is to place the patient in supine position on a fracture table. However, fixing a patient on a fracture table is challenging and time consuming (9). Furthermore, there are difficulties in obtaining lateral imaging of the proximal femur and maintaining the alignment during the surgical procedure with supine positioning. In 2010, Ozkan et al. ${ }^{(10)}$ performed a successful hip nailing surgery in lateral decubitus position with manual traction on a radiolucent table without using a fracture table. In 2012, Connelly et al. ${ }^{(9)}$ reported that lateral decubitus positioning facilitated exposure and reduction in the rates of fixation of complex proximal femoral fractures with locking plate technique. In lateral decubitus positioning, access to both the piriformis fossa and trochanteric entry points is facilitated. More importantly, lateral positioning enables conversion to many open approaches when necessary ${ }^{(11)}$. However, there is no definitive consensus on the best positioning when performing PFN in hip fractures, especially in geriatric patients.

The objective of this study was to compare approaches of supine and lateral decubitus positioning in surgical treatment of intertrochanteric femoral fractures with proximal femoral nailing method in geriatric patients.

\section{MATERIAL and METHODS}

This study had a retrospective design. Reports of epicrisis and X-rays of geriatric patients surgically treated in the orthopedics and traumatology clinic of our hospital using proximal femoral nailing method (PFN) due to intertrochanteric femoral fractures between January 2017 and January 2019 were obtained from the hospital records and analyzed. Patients aged over 65 years treated due to intertrochanteric fractures using PFN method were included in the study. Patients with subtrochanteric fractures, femoral neck fractures, open fractures and pathological fractures were excluded from the study. In addition, fracture types $A 1, A 2$ and $A 3$ based on the $A O$ classification were included in the study, while other proximal femoral region fractures were also excluded. Data of 97 patients who met the inclusion criteria were accessed. The patients were excluded from the study because of a different surgical method used $(n=12)$, due to missing data $(n=11)$, and surgical contraindications due to comorbidities $(n=5)$, and death of 2 patients in the postoperative period. The study was designed with the remaining 67 patients. $\mathrm{X}$-rays of the patients were examined and the fractu- 
T. Kuru, Lateral Decubitus vs Supine Positioning in Surgical Treatment of Hip Fractures with Proximal Femoral Nailing in Geriatric Patients: Whis is more suitable?

res were classified according to the AO system. Patients' demographic data such as age and gender, laterality, mechanism of fracture, duration to the surgery, total duration of hospitalization and length of postoperative stay in the ward were recorded. In addition, patients' position during the procedure, number of shots received from portable X-ray devices, postoperative amount of blood loss, operative time, duration of postoperative follow-up, presence of postoperative bleeding, perioperative complications and postoperative late complications were also recorded and analyzed.

\section{Ethical considerations}

Before the beginning of the study, the necessary ethics approval was received from the local ethics committee of our hospital with the decision dated 06/12/2019 and numbered 2019-12 This study was conducted in accordance with the ethical principles of the Declaration of Helsinki.

\section{Statistical analysis}

Data obtained in this study were statistically analyzed using IBM Statistical Package for Social Sciences (SPSS) Statistics version 22.0 software (SPSS Inc., Chicago, IL, USA). Normality of the variables was tested using Kolmogorov-Smirnov method. Nonnormally distributed variables were analyzed with non-parametric tests. Categorical variables were compared using Chi-square test. Non-normally distributed continuous variables were analyzed with Mann-Whitney $U$ test, and categorical variables with Chi-square test. Quantitative data were expressed as mean, standard deviation, median, interquartile range, minimum and maximum values. $p<0.05$ values were considered statistically significant.

\section{RESULTS}

A total of 67 patients treated due to intertrochanteric fractures using proximal femoral nailing method in the orthopedics and traumatology clinic of our hospital between January 2017 and January 2019 were included in the study. Of all patients, 26 were male and 41 were female ( $\mathrm{M}: \mathrm{F}=0.6)$. The mean age of the patients was found as $77.6 \pm 7.3$ (min-max: 65-95) years. The mean duration of hospitalization was found as $5.4 \pm 2.21$ (min-max: 2-16) days. When laterality of fractures was examined, fractures were at the right side in 29 and at the left side in 38 patients. The mean duration of follow-up was found as $160.9 \pm 65.87$ days.

Based on the AO classification system; the patients were found to have AO Type $1(n=29)$, AO Type II $(n=24)$ and AO Type $3(n=14)$ fractures. Trauma pattern was found as simple falling in $92.5 \%(n=62)$, judicial case in $3 \%(n=2)$, traffic accident in $3 \%(n=2)$ and occupational accident in $1.5 \%(n=1)$ of the patients (Graphic 1).

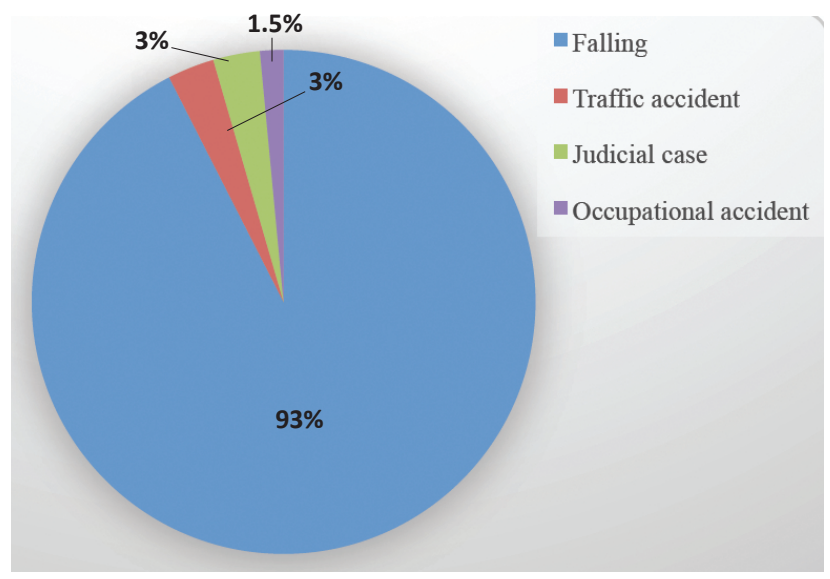

Graphic 1. Distribution of patients according to trauma mechanisms.

Forty $(59.7 \%)$ patients were operated in lateral position and $40.3 \%(n=27)$ of them in supine position (Table 1). The mean operative times were found as $56.8 \pm 5.5$, and $63.7 \pm 1.5$ minutes in patients operated in the lateral, and the supine positions, respectively. There was a statistically significant difference betwe-

Table 1. Distribution of the patients operated in lateral and supine positions.

\begin{tabular}{|c|c|c|c|c|}
\hline & $\% \quad(n)$ & $\begin{array}{c}\text { Mean } \\
\text { operational } \\
\text { time (min) }\end{array}$ & $\begin{array}{l}\text { Amount of } \\
\text { bleeding } \\
\text { (mL) }\end{array}$ & $\begin{array}{c}\text { Number of } \\
\text { perioperative } \\
\text { X-rays }\end{array}$ \\
\hline Lateral & $59.7(n=40)$ & 56.8 & 97.8 & 11.5 \\
\hline Supine & $40.3(n=27)$ & 63.7 & 106.6 & 12.8 \\
\hline
\end{tabular}


en both groups in terms of the mean operative time, which was significantly decreased in the lateral positioning group $(p=0.01)$.

The mean amount of postoperative bleeding was found as $97.8 \pm 3.18 \mathrm{~mL}$ in the lateral and $106.6 \pm 3.9$ $\mathrm{mL}$ in the supine positioning groups. No significant difference was found between the two groups in terms of the amount of postoperative bleeding $(p=0.088)$.

The mean number of X-rays taken during the operation was found as $11.5 \pm 0.27$ shots in the patients operated in lateral position and $12.8 \pm 0.31$ shots in those operated in supine position. There was a statistically significant difference between both groups and the mean number of X-rays taken during the procedures was significantly lower in the lateral positioning group $(\mathrm{p}=0.010)$.

No statistically significant difference was found between the patients operated in lateral or supine positions in terms of the mean duration of hospitalization ( $p=0.712)$. Again, there was no statistically significant difference between both groups in terms of the mean length of postoperative stay in the hospital ( $p>0.05)$.

Perioperative complications were found as anterior cortex perforation in one, and breaking in the distal nail in another patient in the lateral positioning group, while none of the patients operated in supine position developed perioperative complication. During postoperative outpatient clinic follow-up, malunion was found in seven, implant failure and cutout in one, and nonunion in one of the 67 patients. In the analysis of these patients, malunion was observed in 6 , implant failure in one and nonunion in one patient in the lateral positioning group, while malunion was found in one and implant failure in another patient in the supine positioning group (Table 2). No statistically significant difference was found between the patients operated in lateral and supine positions in terms of the incidence of postoperative complications $(p=0.178)$.

Table 2. Postoperative complications of the patients operated in supine and lateral decubitus positions.

\begin{tabular}{lccccc}
\hline & Malunion & $\begin{array}{c}\text { Implant } \\
\text { failure }\end{array}$ & Nonunion & $\begin{array}{c}\text { Anterior cortex } \\
\text { perforation }\end{array}$ & $\begin{array}{c}\text { Fracture in } \\
\text { nail distal }\end{array}$ \\
\hline Lateral & 6 & 1 & 1 & 1 & 1 \\
Supine & 1 & 1 & 0 & 0 & 0 \\
Total & 7 & 2 & 1 & 1 & 1 \\
\hline
\end{tabular}

\section{DISCUSSION}

In the present study we compared lateral decubitus and supine positionings in geriatric patients surgically treated with proximal femoral nail (PFN) method due to intertrochanteric fractures. Studies investigating the use of lateral position for intramedullary nailing are limited. The number of studies evaluating lateral decubitus positioning and supine positioning in the treatment of such fractures is further limited (12). In our study, the mean operative times were found as $56.8 \pm 5.5$, and $63.7 \pm 1.5$ minutes in the patients operated in the lateral and supine positions, respectively. The mean operative time was significantly shorter in the lateral position compared to the supine position. In a study by Sonmez et al. ${ }^{(12)}$ with 82 patients (mean age $=78$ years) surgically treated due to intertrochanteric fractures, the mean operative time was found as $28.70 \pm 7.11$ in the lateral group and $32.08 \pm 7.33$ minutes in the traction table group. In another study by Pahlavanhossaini et al. in which trochanteric and femoral neck fractures were surgically treated in lateral positioning, the mean operative time was reported as $76.5 \pm 16.88$ minutes ${ }^{(13)}$. Again, in a study by Ozkan et al. ${ }^{(10)}$ investigating proximal femoral nailing method performed in lateral position, the mean operative time was found as 44 minutes. The differences among the studies regarding operative times might be resulted from the differences between fracture types, patient groups and definitions of the operative times. Nevertheless our findings are consistent with the ranges of operative times reported in the literature. 
T. Kuru, Lateral Decubitus vs Supine Positioning in Surgical Treatment of Hip Fractures with Proximal Femoral Nailing in Geriatric Patients: Whis is more suitable?

Studies have reported lower blood loss with lateral position compared to supine position. In a study by Xue et al. ${ }^{(14)}$ comparing lateral and supine positioning in surgical treatment of intertrochanteric fractures with PFN, the mean amount of intraoperative bleeding was found as $159.2 \mathrm{~mL}$ in the patients operated in lateral position and $201.5 \mathrm{~mL}$ in those operated in supine position. In our study, the amount of postoperative bleeding was found as $97.8 \pm 3.18 \mathrm{~mL}$ with lateral positioning and $106.6 \pm 3.9 \mathrm{~mL}$ with supine positioning. Although any statistically significant difference was not found between both groups in terms of blood loss, the amount of postoperative bleeding was lower in the patients operated in lateral position. In our study, the mean number of imagings was found as 11.5 in the lateral positioning group and 12.8 in the supine positioning group. The difference between both groups was statistically significant, and this finding suggested that both patients and surgical staff was exposed to less radiation with lateral decubitus position, consistently with previous studies ${ }^{(14)}$.

In the present study, no statistically significant difference was found between the lateral and supine positioning groups in terms of the mean duration of hospitalization. However, there are studies in the literature reporting shorter duration of hospitalization in patients operated in lateral position compared to those operated in supine position ${ }^{(14)}$. In addition, we could not find a significant difference between the two groups in terms of postoperative complications.

Proximal femoral nailing can be performed both in supine and lateral positions. Supine position is preferred in patients with concomitant cervical spine damage and ipsilateral lower extremity fractures. However, access to the greater trochanter may be restricted in supine position. Therefore, lateral position is chosen especially in obese patients ${ }^{(15)}$. Lateral positioning obviates the need for using a fracture table, and facilitates the determination of starting point for intramedullary devices. In the present study, we investigated patients operated in lateral and supine positions. Our results indicated that using lateral position decreases operative time, blood loss and number of scopies compared to supine position. Furthermore, lateral positioning has several advantages over supine positioning that may facilitate surgery. It is easier to determine the greater trochanter and access points with this approach. However, as in all other positions, lateral decubitus position also has some limitations in performing PFN in the treatment of hip fractures in geriatric patients. These patients may not tolerate lateral positioning. In addition, elderly patients with hip fractures may have some conditions that are not suitable for lateral positioning such as unstable spinal fractures, severe pulmonary disease and contralateral lower extremity fractures. Therefore, selection of patients should be carefully undertaken when performing PFN in lateral position.

This study has some limitations. It has a retrospective design and was conducted in a single center. However, the number of patients are relatively high and our follow-up period was sufficiently long. On the other hand, given that studies in the literature comparing PFN results between lateral and supine positioning approaches are limited, further prospective, multicenter and comprehensive studies should be conducted on this issue.

In conclusion; lateral positioning in the surgical treatment of intertrochanteric fractures with proximal femoral nailing method seems to have several advantages over supine position including reduced operative times, blood loss and imaging exposure. Lateral decubitus positioning may be a safe and efficient approach in surgical treatment of intertrochanteric fractures. However, especially geriatric patients should be carefully selected for surgical treatment in this position considering that all geriatric patients may not tolerate lateral position and may have various comorbidities that are not suitable for lateral positioning. 
Ethics Committee Approval: T.C. Çanakkale Onsekiz Mart University Rectorate Clinical Research Ethics Committee approval was obtained (2019-12).

Conflict of Interest: None.

Funding: None.

Informed Consent: As it was a retrospective study, informed consent was not obtained.

\section{REFERENCES}

1. Miyamoto RG, Kaplan KM, Levine BR, Egol KA, Zuckerman JD. Surgical management of hip fractures: an evidence-based review of the literature. I: femoral neck fractures. J Am Acad Orthop Surg. 2008;16(10):596-607. [CrossRef]

2. Panula J, Pihlajamäki $H$, Mattila VM, et al. Mortality and cause of death in hip fracture patients aged 65 or older: a population-based study. BMC Musculoskelet Disord. 2011;20(12):105. [CrossRef]

3. Richmond J, Aharonoff GB, Zuckerman JD, Koval KJ. Mortality risk after hip fracture. J Orthop Trauma. 2003;17(1):53-6. [CrossRef]

4. Egol KA, Koval K, Zuckerman JD. Femoral neck fractures. In: Egol et al. Handbook of fractures. $4^{\text {th }}$ ed. Philadelphia: Wolters Kluwer/Lippincott Williams \& Wilkins Health; 2010. pp. 360-71. 9.

5. Fung W, Jonsson A, Buhren V, Bhandari M. Classifying intertrochanteric fractures of the proximal femur: does experience matter? Med Princ Pract. 2007;16(3):198-202. [CrossRef]

6. Ahrengart $L$, Törnkvist $H$, Fornander $P$, et al. A randomized study of the compression hip screw and Gamma nail in 426 fractures. Clin Orthop Relat Res. 2002;(401):209-22. [CrossRef]

7. Halder SC. The gamma nail for peritrochanteric fractures. J Bone Joint Surg Br. 1992;74(3):340-4. [CrossRef]

8. Herrera A, Domingo LJ, Calvo A, Martínez A, Cuenca J. A comparative study of trochanteric fractures treated with the Gamma nail or the proximal femoral nail. Int Orthop. 2002;26(6):365-9. [CrossRef]

9. Connelly CL, Archdeacon MT. The lateral decubitus approach for complex proximal femur fractures: anatomic reduction and locking plate neutralization: a technical trick. J Orthop Trauma. 2012;26(4):252-7. [CrossRef]

10. Ozkan K, Cift H, Akan K, Sahin A, Eceviz E, Ugutmen E. Proximal femoral nailing without a fracture table. Eur $\mathrm{J}$ Orthop Surg Traumatol. 2010;20(3):229-31. [CrossRef]

11. Bishop $A B$, Rodriguez $\mathrm{K}$. Closed intramedullary nailing of the femur in the lateral decubitus position. J Trauma. 2010;68(1):231-5. [CrossRef]

12. Sonmez MM, Camur S, Erturer E, Ugurlar M, Kara A, Ozturk I. Strategies for Proximal Femoral Nailing of Unstable Intertrochanteric Fractures: Lateral Decubitus Position or Traction Table. J Am Acad Orthop Surg. 2017;25(3):e37-e44. [CrossRef]

13. Pahlavanhosseini $\mathrm{H}$, Valizadeh $\mathrm{S}$, Banadaky $\mathrm{SH}$, Karbasi $\mathrm{MH}$, Abrisham SM, Fallahzadeh H. Management of Hip Fractures in Lateral Position without a Fracture Table. Arch Bone Jt Surg. 2014;2(3):168-73.

14. Xue L, Zha L, Chen $Q$, et al. Randomized controlled trials of proximal femoral nail antirotation in lateral decubitus and supine position on treatment of intertrochanteric fractures. Scientific World Journal. 2013;27:276015. [CrossRef]

15. Aiyer S, Jagiasi J, Argekar H, Sharan S, Dasgupta B. Closed antegrade interlocked nailing of femoral shaft fractures operated up to 2 weeks postinjury in the absence of a fracture table or C-arm. J Trauma. 2006;61(2):457-60. [CrossRef] 